\title{
Review
}

\section{Reading Walzer}

Yitzhak Benbaji and Naomi Sussman

Routledge, London and New York, 2014, x+342 pp., US \$46.95,

ISBN: 978-0415780315

Contemporary Political Theory (2015) 14, e22-e25. doi:10.1057/cpt.2014.7;

published online 21 October 2014

Michael Walzer has made important contributions to fields as diverse as just war theory, distributive justice, multiculturalism and the foundations of normative principles, yet not much work has been done tying together the disparate strands.

Reading Walzer, which combines analyses of his views on the moral standing of states, multiculturalism, complex equality and justice in war, is thus an invaluable addition to the literature. Orend (2000) was previously the most comprehensive account, connecting Walzer's theories of justice and war, but concentrating mostly on the latter. Naomi Sussman's introduction shows oft-neglected connections between aspects of Walzer's thought, grounding it in a meta-ethic that 'combines humanism and communitarianism' (p. 3) and rests on the belief that actual human beings are what matter morally, the claim that meaning depends on particular communities, and the view that a good human life is a meaningful one (pp. 3-6). This explains why Walzer adopts an interpretive approach to theorizing about justice, arguing that particular communities' shared understandings about particular goods must be the basis of distributive principles (pp. 9-14). It also underlies his statism, exemplified by his insistence on the 'moral equality of soldiers' (the view that soldiers are not responsible for judging the justice of their state's cause) and by his emphasis on the right to collective self-determination (pp. 4-5, 14-16). Finally, it recurs in his account of cultural accommodation as resting on different principles in 'Old World' nation-states and 'New World' immigrant societies (pp. 6-8, 129-145).

In the rest of the volume, leading scholars engage with Walzer's arguments on four major issues: the moral standing of states, cultural diversity, the spheres of justice, and just war theory. Throughout the discussion, the major theme is the scope of moral judgments. Although Walzer tends to dislike the label of 'communitarian', Sussman's invocation of it is not novel: many (cosmopolitan) critics have argued that Walzer places too much normative weight on the communal determination of meaning. In Reading Walzer, Jeff McMahan exemplifies this view, reiterating his long-standing objection to the 'moral equality of soldiers' by suggesting an informal

(C) 2015 Macmillan Publishers Ltd. 1470-8914 Contemporary Political Theory Vol. 14, 1, e22-e25 www.palgrave-journals.com/cpt/ 
international court that would adjudicate on the justice of resort to war, so as to relieve the epistemic burden on soldiers (pp. 233-255). In similar vein, Charles Beitz insists that Walzer's appeal to self-determination is too 'minimalist', and should be reformulated into an 'intermediate' version that, while not insisting that a self-determining state be democratic, does mandate that 'the institutions of a selfdetermining state should place its members in a position to influence their own collective destiny' (p. 75). George Kateb's attack on Walzer's 'radical conservatism' (p. 197), on the grounds that 'connected criticism' gets insufficient distance from social norms while simultaneously flying in the face of modern individualism, is the sharpest critique in the book.

Reading Walzer juxtaposes these critical perspectives with defenses of Walzer. Against Beitz, Ruth Gavison and Michael Doyle highlight the dangers of intervention, with Gavison noting the importance of states in providing a 'framework of participation' (p. 44), and Doyle reiterating Mill's claim that only secure national borders can provide a framework for freedom, and adding that many purported exemptions to the non-intervention principle do not work (pp. 83-103). Yitzhak Benbaji makes a similar argument to Gavison in countering McMahan's proposal, suggesting that an institutionalized cosmopolitan court would undermine the de jure sovereignty of states and so make fair political participation less meaningful (pp. 256-276). David Luban suggests that the distinction between cosmopolitan and communitarian positions may be less stark than we are wont to presume, defending Walzer's reformulation of the Doctrine of Double Effect - that soldiers must accept risks to themselves in order to provide due care to enemy civilians - on the grounds that soldiers are the ones imposing the danger (pp. 277-301).

This comprehensive coverage makes Reading Walzer the first thorough guide to Walzer's political thought, yet it is not, for that, complete. The most notable omission is Walzer's 'supreme emergency' argument, which calls for overriding principles of jus in bello in cases of catastrophic threats to national survival (Walzer, 2006, pp. 251-268). However, Nancy Sherman does touch on his 'dirty hands' argument (p. 322), and supreme emergencies are best understood as examples of dirty hands dilemmas.

Although Reading Walzer is admirably broad thematically, it is somewhat narrow in disciplinary and methodological terms. Like most of the secondary literature on Walzer, it contains little attempt to situate Walzer's thought historically. Instead, most of the chapters treat his arguments as analytic propositions that stand for themselves. There are exceptions: Bonnie Honig relies in part on Derridean deconstruction and an analogy with Gershom Scholem's arguments about the dangers of using a sacred language (Hebrew) for secular purposes (pp. 147-150) when she argues that Walzer's attempt to use the Exodus story for secular purposes cannot escape its sacred elements (pp. 150-157). Sherman appeals to psychoanalysis for development of the notion of the 'moral psychic reality' of war (pp. 302-327). But none engages in the type of historical work advanced by the likes of Skinner, Pocock and Dunn, who hold that 
understanding philosophical arguments requires knowing what the author was doing and thus knowledge of the social context in which the work was produced (Skinner, 1988, p. 30). This is striking in light of Walzer's own claim that many of his most famous contributions to political theory are motivated by particular political engagements. For example, he decided to write Just and Unjust Wars in order to systematize his understanding of the reasons to oppose the Vietnam War (Walzer, 2006, p. xx). Likewise, he spent much of the 1980s arguing that American shared understandings of the good of medical care were such as to mandate universal provision because he wished to combat Reaganomics (Walzer, 1986, p. 11).

Jacob Levy does, it is true, situate Walzer's work on membership in the context of the lifting of racist restrictions on immigration from the 1960s onwards (pp. 117118). Will Kymlicka notes that Walzer insists that multicultural policies must be tailored to the histories of the countries in which they are applied (pp. 130-132). And Michael Sandel applies Walzer's notion of 'blocked exchanges' to the ever-onward march of market logic (pp. 177-178). Yet these are all examples of the general context in which Walzer wrote, and do not engage with the particular perspective that Walzer brought to their interpretation. They are contextual in the way that saying that Hobbes wrote against the backdrop of the English revolution is contextual, not in the more specific sense of saying that he was involved in the arguments about the 'Engagement' to obey the new republic.

Contextualizing Walzer's work would, I think, require taking seriously his involvement with Dissent magazine, which he edited from 1993 until 2013. Walzer joined the magazine's staff shortly after its establishment in 1954, so his 60-year involvement stretches back almost to boyhood. Whereas Sussman mentions this (p. 2), and several authors discuss articles he published in it, nobody considers the influence of Dissent on Walzer's thought. Bearing in mind that Walzer credits Dissent's founders, Irving Howe and Lewis Coser, with inspiring him to 'become an intellectual' and with teaching him that there was a political space between liberalism and communism that was worth inhabiting (Walzer, 2013, p. 104), this influence seems to have been considerable.

Situating Walzer in this way can help to explain the origins of some of his seemingly idiosyncratic positions. For example, Levy argues that Walzer's notion of shared understandings reflects a commitment to the Rawlsian notion of 'wellorderedness' that leads to a surprising lack of pluralism in his analysis of the internal makeup of states, and that he ought to allow for a greater degree of 'dissensus' (pp. 121-123, 126). Yet, on Walzer's view, shared understandings refer merely to the fact that 'dissensus' is framed around a shared cultural discourse (p. 170; Walzer, 1995). This, which I have termed the quest for an 'overlapping dissensus' (Reiner, 2013), holds political life to be the perpetual reopening of old debates (Walzer, 1981) and affirms that, rather than hoping for ultimate victory, ideological perspectives such as communitarianism and liberalism must learn to sit alongside each other (Walzer, 1990). Howe argued that liberalism and social democracy had learned to co-exist in 
just this way, and the article in which he put forward this position includes a comment by Walzer on the draft (Howe, 1985, p. 164).

The great achievement of Reading Walzer is to show that, in all its manifestations, Walzer's work is animated by a coherent vision. That vision challenges the assumptions of many of his interlocutors by taking meaning to emanate from particular communities. It would be a useful next step in the literature if more scholars considered the ways in which Walzer's own work has developed out of the milieux in which he writes.

\section{References}

Howe, I. (1985) Socialism and America. San Diego, CA: Harcourt Brace Jovanovich.

Orend, B. (2000) Michael Walzer on War and Justice. Cardiff, UK: University of Wales Press.

Reiner, J. (2013) Toward an overlapping dissensus: The search for inclusivity in the political thought of Dissent magazine. Political Research Quarterly 66(4): 755-766.

Skinner, Q. (1988 [1969]) Meaning and understanding in the history of ideas. In: J. Tully (ed.) Meaning and Context: Quentin Skinner and His Critics. Cambridge, UK: Polity Press, pp. 29-67.

Walzer, M. (1981) Philosophy and democracy. Political Theory 9(3): 379-399.

Walzer, M. (1986) The long-term perspective. Bulletin of the New York Academy of Medicine 62(1): 8-14.

Walzer, M. (1990) The communitarian critique of liberalism. Political Theory 18(1): 6-23.

Walzer, M. (1995) Shared meanings in a poly-ethnic democratic setting. Journal of Religious Ethics 22(2): 401-405.

Walzer, M. (2006 [1977]) Just and Unjust Wars: A Moral Argument with Historical Illustrations. New York: Basic Books.

Walzer, M. (2013) Becoming a Dissentnik. Dissent 59(1): 104.

J. Toby Reiner

Dickinson College, Carlisle, PA 17013, USA reinerj@dickinson.edu 